\section{ONOMÁVAEIN}

Revista semestral de lingüística, filología y traducción
PONTIFICIA UNIVERSIDAD

CATÓLICA DE CHILE

CATOLICA DE CHILE
FACULTAD DE LETRAS

\title{
Atlantic Spanish vocabulary: Contribution from the corpus of dialectal lexicon
}

\author{
$\mathbf{M}^{\mathbf{a}}$ Teresa Cáceres-Lorenzo \\ Universidad Las Palmas de Gran Canaria \\ España
}

ONOMÁZEIN 32 (diciembre de 2015): 339-352

DOI: 10.7764/onomazein.32.20

\section{(c) $\odot$}

Ma Teresa Cáceres-Lorenzo: Instituto Universitario de Análisis y Aplicaciones Textuales, Universidad Las Palmas de Gran Canaria, España. | Correo electrónico: mcaceres@dfe.ulpgc.es 


\section{Abstract}

The analysis of the dialectic vocabulary common to Andalusia and the Canary Islands (Spain) reveals the regional concurrences of Atlantic Spanish. Previous studies have defined these concurrences generally but have not established quantitative connections between the Peninsular and American regional variations. This paper reviews these possible lexical connections using recently published synchronic regional dictionaries. A quantitative and qualitative approach is employed to analyse a collection of Canary-Andalusian words, with the objective of recognising the level of concurrence in the dialectic group. The results reveal three distinct representative networks: a) Canary-Andalusian and American; b) Canary-Andalusian and concurrences with the Western and Eastern Iberian Peninsula; and c) Canary-Andalusian and Northern peninsular and Castilian words. These results clearly demonstrate the process of basic interference and the behaviour of the diffusion of the dialectic lexicon.

Keywords: Spanish dialectology; regional lexicon; Canary Islands; Andalusia; Western America. 


\section{Introduction}

The Atlantic Spanish vocabulary formed through a complex process of contact and levelling during the colonial period (Fontanella de Weinberg, 1987; Granda, 1994). The distinct peninsular cultural and linguistic subsystems found in these new territories were directly and indirectly disseminated through the Andalusian linguistic norms of Seville. At the same time, the Andalusian dialect was formed from minor CataIonian and Aragonese contributions to Eastern Andalusia during the Reconquista period and coIonisation through contact with Murcia. Meanwhile, those speakers with Western vocabularies (Leonese, Galicians and Portuguese) found themselves preferentially located in Baetica (Western Andalusia), particularly in the provinces of Huelva and Seville (Frago Gracia, 1990: 157). The idea that the Spanish lexicon is a dialectic grouping has been present implicitly for decades in all of the research on Iberian Peninsular and American Spanish (Corominas, 1944; García de Diego, 1950; Buesa Oliver, 1990).

However, the previous research has not reviewed the contribution of each regional variation to this new Atlantic koine using the newly published regional dictionaries. Synchronic dialectal lexicons facilitate the recognition of the relationships among regional variations. In this research, dialectal vocabulary is defined as those linguistic signs exclusive from a given geographical area. In the Canary Islands there are also words that appear in many different lexicons available in South America and mainland Spain geolects. To this vocabulary, we incorporate general words that are considered semantic dialectalisms; as in the regional corpora we used for this research, we also include words that present changes in the signifier, product of a phonetic change (Alvar, 1990; Corrales Zumbado, 1996)

In studies of Atlantic Spanish, the existence of a lexicon composed of words that concur with other peninsular or American linguistic areas is evident (Catalán, 1958; Navarro Carrasco, 1988; Buesa Oliver, 1990; Frago Gracia, 1994; Alvar, 1996; Rivarola, 2007; Narbona Jiménez, Cano Aguilar \& Morillo-Velarde Pérez 2011; López Serena, 2013; Oesterreicher, 2002). Regional dictionaries were developed following the general criterion of reflecting the distinguishing aspects of each of the regions. The use of these corpora in this research will affect the obtained results and the geographical areas with which we establish a comparison. In the macrostructure of the dictionaries there are slang words or phonic-graphic variations from the colloquial register of a specific geographical area, which is not always justified in corpora that aimed at diatopical variation. At the same time, these regional corpora present geographic information that allows comparison across regions.

Our research sought to obtain quantitative data on the characteristics of the interregional vocabulary in peninsular and overseas Spanish. To this end, a quantitative and qualitative method based on contemporaneous dialectal dictionaries was employed to analyse the lexical concurrence between Canary and Western Andalusia as well as the lexical concurrence of these dialects with those spoken in other Hispanic areas.

\section{Theoretical framework}

The conclusions of studies on the Canary Island vocabulary and its possible concurrence with other territories can be summarised with respect to the following theoretical issues.

a) In the Atlantic literature, researchers consider Canary speech to be a variation in which a significant number of terms that coincide with other pan-Hispanic areas have endured (Alvar, 1996). The linguistic variety of the Canary Islands is a diatopic variation of southern Spanish and is situated in the Atlantic context. The Canary Islands consist of seven islands (Tenerife, La Palma, La Gomera, El Hierro, Gran Canary, Fuer- 
teventura and Lanzarote) located close to Africa between 27 and 29 degrees north latitude and 13 and 18 degrees east longitude.

The historical, social, and cultural links between the Canary Islands and Andalusia originate in the long-standing relationship between their ports, which began at the end of the fifteenth century (Alvar, 1990; Frago Gracia, 1994; and, more recently, Medina López, 2013; Lüdtke, 2013; Cáceres Lorenzo, 2015). Canary's social and linguistic origins include Western and Southern peninsular influences. Substantial socio-historic and cultural evidence supports the presence of Andalusians and other populations from the southern areas of the Iberian Peninsula in the Canary Islands, an island territory that conserves words from those areas (Alvar, 1996; Cáceres Lorenzo, 2012; Medina López, 2013). Andalusian and Canary vocabulary exhibit a common dialectal lexicon (Navarro Carrasco, 1988; Buesa Oliver, 1990; Frago Gracia, 2000) that spread to Atlantic American territories during the various phases of Spanish language settlement in these new areas. It has been affirmed that Canary is an intermediate variation between the standard and the dialect, whose polymorphism, synonymy, and lexical richness result from the numerous social and linguistic contacts produced through the history of the islands' commercial ports (Morgenthaler García, 2008).

On the linguistic level, Canary's geographic situation has promoted the richness of its vocabulary, in which there are distinct manners of communicating the same meaning. This lexical polymorphism means that the lexical contributions to Canary remain stable and constant, which is useful for analysing the Spanish spoken in the Canary Islands as well as other American variations (Lope Blanch, 1981). This phenomenon has traditionally been supported in historical and social testimonies but has not been previously studied using quantitative data (Lebsanft, Mihatsch \& Polizin-Hauman, 2012: 11).

The region's geographic insularity gives the Spanish spoken in the Canaries a communicati- ve context distinct from that of continental regions, as is also the case for Caribbean islands (Alba, 1995; Rivarola, 2007; Morgenthaler García, 2008; Corrales Zumbado \& Corbella Díaz, 2012). In the continental context, the Spanish dialects spoken in each region are in permanent contact with one another, with intermediate zones of lexical intersection in which it is complicated to discern which modality is spoken. Contact in these continental areas is continuous in space and time, and interferences among distinct varieties are constant (Elizaincín, 2007; Granda, 2003 in a general sense; and lately, Figueroa Arencibia, 2009 for Cuba; Claes, 2011 for the Caribbean; Bravo-García \& Cáceres-Lorenzo, 2011, in the Canary communicative context).

b) Recognising the lexical characteristics of Andalusian (Almeria, Cadiz, Cordoba, Granada, Huelva, Jaen, Malaga and Seville) is a complex problem. Andalusia is a Reconquista region situated at the southern end of the Iberian Peninsula that experienced its own linguistic levelling before the discovery of America. It also influenced the levelling of Atlantic Spanish. To understand its dialectal variation in principle, it is necessary to account for the linguistic influences that it received from the north: influxes from the west via Extremadura, from the north via romance Castilian, and from Catalan-Aragonese through Murcia (Alvar, 1964: 9; Lüdtke, 1998: 513). The Canary linguistic variation inherits these characteristics in a situation similar to the arrival of the Spanish language in the Americas. Among the distinct Spanish regions, there is a common interregional continuum in distinct communicative spaces (Salvador, 1987; Alvar, 1990), for which no quantifiable data are available.

Both the Andalusian and Canary lexica experienced elemental processes of contact and interference compared with other dialectal varieties. This phenomenon is termed "lexical borrowing only" because only a small cultural component is transferred (Thompson \& Kaufman, 1988: 70). 
These issues result in the following research questions: How many lexical concurrences with other varieties can be confirmed in the CanaryAndalusian synchronic dialectal vocabulary? In analysing these common terms, which networks or groups can be identified with other Peninsular or American dialectal varieties?

\section{Materials and methods}

To answer these research questions, a quantitative and qualitative method was applied to a database created from the following lexicographic corpora: Diccionario Diferencial del Español de Canarias (Corrales Zumbado, Corbella Díaz \& Álvarez Martínez, 1996) and Diccionario ejemplificado de canarismos (Corrales Zumbado \& Corbella Díaz, 2009). The examples obtained have been corroborated with a number of regional dictionaries (Iribarren \& Ollaquindia, 1984; Rohlfs, 1985; Rincón Alonso, 1991; Sáiz Barrio, 1991; Neira Martínez \& Piñeiro, 1998; Sevilla Pérez, 1990; Montero Curiel, 1997; Le Men Loyer, 1998; Alvar Ezquerra, 2000; Hernández Alonso, 2001; Asociación de Academias de la Lengua Española, 2010). Our research design included two phases: a) Compilation of a Canary-Andalusian lexical corpus from the synchronic dialectal dictionaries.

b) Search for concurrences between CanaryAndalusian and other peninsular or American regions. These geographic zones have been divided into eight territorial areas: Aragon and the eastern coast, Murcia, Castile (Castile-La Mancha, Madrid and the former Old Castile), the Northern peninsula (Navarre, Rioja, Basque country, Santander, and Asturias), and the Western peninsula (Galicia, Leon, Zamora, Salamanca, and Extremadura) and three American areas: the Caribbean, Mesoamerica and South America. The choosing of eight areas is influenced by the information given in the regional dictionaries we have selected for this research.

A presence-absence table has been elaborated to relate the words analysed with the different regions. As an example, Table 1 shows the first ten terms of this longer table. To better understand the results, it was determined to treat Andalusia as a separate region, although all of the words have the same value (one) because only words present in the Andalusian vocabulary are included in the table.

\section{TABLE 1}

Part of the presence-absence table used to obtain the similarity index of the lexical groups analysed $(1=\mathrm{Andalusia;} 2=$ Aragon and the eastern coast; $3=$ Murcia; 4 = Castile; $5=$ Northern peninsula; $6=$ Western peninsula; $7=$ Caribbean; $8=$ Mesoamerica; 9 = South America)

\begin{tabular}{|c|c|c|c|c|c|c|c|c|c|}
\hline \multicolumn{10}{|c|}{ Lexical and semantic concurrences by region } \\
\hline \multirow{2}{*}{$\begin{array}{l}\text { Dialectal phrase from Canary } \\
\text { Island speech }\end{array}$} & \multicolumn{6}{|c|}{$\begin{array}{l}\text { Peninsula } \\
\end{array}$} & \multicolumn{3}{|c|}{ America } \\
\hline & $\begin{array}{l}1 \\
\text { Andalusia }\end{array}$ & $\begin{array}{l}2 \\
\text { Aragon/eastern } \\
\text { coast }\end{array}$ & $\begin{array}{l}3 \\
\text { Murcia }\end{array}$ & $\begin{array}{l}4 \\
\text { Castile }\end{array}$ & $\begin{array}{l}\mathbf{5} \\
\text { Northern } \\
\text { peninsula } \\
\end{array}$ & $\begin{array}{l}6 \\
\text { Western } \\
\text { peninsula } \\
\end{array}$ & \begin{tabular}{l|}
$\mathbf{7}$ \\
$\mathbf{C}$
\end{tabular} & $\begin{array}{l}\mathbf{8} \\
\mathbf{M}\end{array}$ & $\begin{array}{l}9 \\
\mathrm{~S}\end{array}$ \\
\hline ¡Ángela María! [Angel Mary!] & 1 & 0 & 0 & 0 & 0 & 0 & 1 & 1 & 1 \\
\hline ¡Carrizo! & 1 & 0 & 0 & 0 & 0 & 0 & 0 & 1 & 1 \\
\hline $\begin{array}{l}\text { iFo! } \\
{[\text { Stinky!] }}\end{array}$ & 1 & 0 & 0 & 1 & 0 & 1 & 1 & 1 & 1 \\
\hline $\begin{array}{l}\text { Abanador } \\
\text { [Fan used to stoke a fire] }\end{array}$ & 1 & 0 & 0 & 0 & 0 & 0 & 1 & 1 & 1 \\
\hline $\begin{array}{l}\text { Aberruntar } \\
\text { [Predict the future] }\end{array}$ & 1 & 0 & 1 & 0 & 0 & 1 & 0 & 0 & 0 \\
\hline
\end{tabular}




\begin{tabular}{|l|l|l|l|l|l|l|l|l|l|}
\hline $\begin{array}{l}\text { Abicharse } \\
\text { [To fill with maggots] }\end{array}$ & 1 & 0 & 0 & 0 & 0 & 0 & 0 & 0 & 1 \\
\hline $\begin{array}{l}\text { Abombado } \\
\text { [Arrogant] }\end{array}$ & 1 & 0 & 1 & 0 & 0 & 0 & 1 & 1 & 1 \\
\hline $\begin{array}{l}\text { Acacharse } \\
\text { [To squat] }\end{array}$ & 1 & 0 & 1 & 0 & 0 & 0 & 0 & 0 & 0 \\
\hline $\begin{array}{l}\text { Aceituno } \\
\text { [Olive tree] }\end{array}$ & 1 & 0 & 0 & 1 & 0 & 0 & 1 & 0 & 0 \\
\hline $\begin{array}{l}\text { Adivina } \\
\text { [Riddle] }\end{array}$ & 1 & 0 & 1 & 0 & 0 & 0 & 0 & 0 & 0 \\
\hline
\end{tabular}

Using the data in this table, it is possible to calculate the similarity index among the different groups of concurrences. Jaccard's similarity index $\left(\boldsymbol{I}_{\boldsymbol{J}}\right)$ is used to facilitate the measurement of similarity, dissimilarity, or distances that exist between two samples (Gries, 2009; Ueda, 2013). Jaccard's index calculates the proportion of common types among two samples compared with the total number of types. Possible values for the Jaccard coefficient are defined as $[0,1]$. The formula is as follows:

\section{$\mathrm{I}, \mathrm{c} /(\mathrm{a}+\mathrm{b}+\mathrm{c})$}

where:

- $a$ : is the number of terms registered in the region or territory $A$ that are not in $B$.

- $\mathbf{b}$ : is the number of terms found in region $B$ but not $A$.

- c: is the number of terms found in both regions or territories.

For example, to calculate the similarity index between the lexicon considered differentiaIly concurrent with Andalusia and with the Murcian enclaves and the Caribbean, the following calculations were performed: $\mathrm{a}=$ number of differential phrases shared with Andalusia and the Caribbean but not recorded in Murcia $=194$

$b=$ number of differential phrases shared with Andalusia and the Murcian region but not recorded in the Caribbean $=91$

$c=$ number of differential phrases shared with Andalusia, the Caribbean, and Murcia = 33

$$
\mathrm{I}_{\mathrm{J}}=33 /(194+91+33)=0.104
$$

With this similarity index, an ascending hierarchical classification was conducted to order the territories studied into classes and enable us to sort each group's lexical concurrence according to similarity. This classification was performed in Excel using the Addinsoft XLSTAT 2013 application.

\section{Results and discussion}

At total of 998 Canary terms shared with Andalusia were obtained from the dialectal dictionaries. Included in this corpus are 572 phrases that also concur with other Spanish-speaking regions (Table 2 ).

\section{TABLE 2}

Number of Canary-Andalusian regional words that concur with the other regions studied $(2=$ Aragon and the eastern coast; 3 = Murcia; 4 = Castile; 5 = Northern peninsula; 6 = Western peninsula; 7 = Caribbean; $8=$ Mesoamerica; $9=$ South America). Number 1 is Andalusia, which does not appear in this table because its concurrence is 100\% (572)

\begin{tabular}{|l|l|l|l|l|l|l|l|l|}
\hline Region & $\begin{array}{l}\mathbf{2} \\
\text { Aragon and } \\
\text { eastern coast }\end{array}$ & $\begin{array}{l}\mathbf{3} \\
\text { Murcia }\end{array}$ & $\begin{array}{l}\mathbf{4} \\
\text { Castile }\end{array}$ & $\begin{array}{l}\mathbf{5} \\
\text { Northern } \\
\text { peninsula }\end{array}$ & $\begin{array}{l}\mathbf{6} \\
\text { Western } \\
\text { peninsula }\end{array}$ & $\begin{array}{l}\mathbf{7} \\
\text { C }\end{array}$ & $\begin{array}{l}\mathbf{8} \\
\text { M }\end{array}$ & $\begin{array}{l}\mathbf{9} \\
\text { S }\end{array}$ \\
\hline $\begin{array}{l}\text { Number of } \\
\text { concurrences }\end{array}$ & 129 & 124 & 48 & 58 & 203 & 227 & 190 & 319 \\
\hline
\end{tabular}


The group with the highest number of concurrences consists of the Canary Islands, AndaIusia, and South America, with 319 words. South America's great expanse could be a factor in this outcome. However, the smallest American area (the Caribbean) also has a large number of concurrences. The historical and social relationships of the West Indies explain this concomitance (Navarro Carrasco, 1988; Frago Gracia, 1994; Corrales Zumbado \& Corbella Díaz, 2013).

Among the peninsular areas, the Western peninsula has the largest number of concurrences with the Canary Islands and Andalusia. Andalusia's geographic and historic proximity to this region facilitated this important linkage. But this relationship is evident with the Western region of Andalusia, and not always with the Eastern (Ariza Viguera, 1995; Alvar, 1996; Cáceres Lorenzo, 2015). The borrowing of Portuguese words into the Spanish language has occurred frequently (Salvador, 1967). The centuries of shared history between Portugal and the Spanish border areas is evidenced through multiple historical, social, cultural, and economic relationships (Pérez Vidal, 1991; CorbeIla Díaz y Medina López, 1996). It is not an anomaly to discover that certain examples registered in the Canary Islands and Andalusia represent a vocabulary shared with peninsular territories perhaps before the fifteenth century (Medina López, 2013).
Leonese, Extremadurans and Andalusians actively collaborated in Canary-American businesses and for years had extensive contact with one another, as is evidenced in overseas Spanish.

In certain regions, the level of lexical concurrence is high (Table 3 ). Nearly $63 \%$ of this lexicon is found in the vocabulary of the Canary Islands, Andalusia, and at least two other regions analysed in this study.

Words with substantial regional extension are rare. In an analysis of words common to more than seven regions (Table 4), certain general characteristics of the Atlantic lexicon can be observed: archaisms, lexical westernisms, lexical or semantic neologisms, maritime terms, and indigenous American (nagua) words.

There is a considerable difference between the number of terms that concur in five regions (23\%) and those that concur in six regions (8.7\%). This difference is because of the previously noted number of words registered in the Americas, which includes three of the regions examined by this study. The high number of words in this region produces a quantitative change because there are many concurrent words used in the Canary Islands, Andalusia, and the Americas.

Table 5 shows the proximity matrix elaborated by calculating the jaccard similarity index.

\section{TABLE 3}

Level of interregional dialectal lexical concurrence

\begin{tabular}{|c|c|c|}
\hline $\begin{array}{c}\text { Number of concurring regions (including the } \\
\text { Canary Islands and Andalusia) }\end{array}$ & Number of terms & $\%$ \\
\hline 3 & 212 & 37.06 \\
\hline 4 & 140 & 24.47 \\
\hline 5 & 133 & 23.25 \\
\hline 6 & 50 & 8.74 \\
\hline 7 & 20 & 3.49 \\
\hline 8 & 13 & 2.27 \\
\hline 9 & 3 & 0.52 \\
\hline 10 & 1 & 0.17 \\
\hline
\end{tabular}




\section{TABLE 4}

Canary-Andalusian words used in more than seven of the regions analysed in this study $(1=$ Andalusia $[A] ; 2=A r a g o n$ and the Eastern coast $[\mathrm{Ar}] ; 3=$ Murcia [Mu]; $4=$ Castile [Cast]; $5=$ Northern peninsula [N]; $6=$ Western peninsula [O]; $7=$ Caribbean [C]; 8 = Mesoamerica [M]; 9 = South America [S]). The search for origins (DRAE; Buesa Oliver \& Enguita Utrilla 1992; DEC; DA): (Arch.) = archaism; (Afric.) = African; (Ind.) = Indigenous American word; (W) = lexical westernism

\begin{tabular}{|c|c|c|c|c|c|c|c|c|c|}
\hline \multirow[b]{2}{*}{ Canary words in more than seven regions } & \multicolumn{6}{|c|}{ Peninsula } & \multicolumn{3}{|c|}{ America } \\
\hline & \begin{tabular}{l|l}
1 \\
$(\mathbf{A})$
\end{tabular} & \begin{tabular}{|l|l|}
2 \\
$(A r)$ \\
\end{tabular} & $\begin{array}{l}3 \\
\text { (Mu) }\end{array}$ & \begin{tabular}{|l|}
4 \\
(Cast)
\end{tabular} & $\begin{array}{l}5 \\
(N)\end{array}$ & $\begin{array}{l}6 \\
(0)\end{array}$ & $\begin{array}{l}7 \\
(\mathrm{C})\end{array}$ & \begin{tabular}{|l|l|}
8 \\
$(\mathbf{M})$ \\
\end{tabular} & $\begin{array}{l}9 \\
(\mathbf{S})\end{array}$ \\
\hline Azafate 'bandeja' [tray] (Arch. from Arabic) & 1 & 1 & 1 & 1 & 1 & 1 & 1 & 1 & 1 \\
\hline Alcayata 'escarpia' [hook] (Arch. from Arabic) & 1 & 0 & 1 & 1 & 1 & 1 & 1 & 1 & 1 \\
\hline Contino, na (de) 'de continuo' [constant] (Arch.) & 1 & 1 & 1 & 1 & 0 & 1 & 1 & 1 & 1 \\
\hline Desagerar 'exagerar' [exaggerate] & 1 & 1 & 1 & 0 & 1 & 1 & 1 & 1 & 1 \\
\hline Chiminea 'chimenea' [fireplace] & 1 & 1 & 1 & 1 & 0 & 1 & 1 & 0 & 1 \\
\hline Desinquieto 'inquieto' [restless] (W) & 1 & 1 & 1 & 1 & 0 & 1 & 1 & 1 & 0 \\
\hline Dimpués 'después' [after] & 1 & 1 & 1 & 1 & 1 & 1 & 1 & 0 & 0 \\
\hline Dir 'ir o marchar' [to go or to march] (Arch.) & 1 & 1 & 1 & 1 & 0 & 1 & 1 & 0 & 1 \\
\hline Ende 'desde' [from] (Arch.) & 1 & 1 & 1 & 0 & 1 & 1 & 1 & 0 & 1 \\
\hline Jaca 'gallo inglés de pelea' [English fighting cock] & 1 & 1 & 1 & 0 & 0 & 1 & 1 & 1 & 1 \\
\hline $\begin{array}{l}\text { Nagua 'saya interior de tela blanca' [white petticoat] } \\
\text { (Ind.) }\end{array}$ & 1 & 1 & 1 & 0 & 0 & 1 & 1 & 1 & 1 \\
\hline Priesa 'prisa' [rush] (Arch.) & 1 & 1 & 1 & 1 & 0 & 1 & 1 & 0 & 1 \\
\hline $\begin{array}{l}\text { Almuerzo 'Primera comida del dia' [first meal of the } \\
\text { day] (Arch.) }\end{array}$ & 1 & 1 & 0 & 0 & 1 & 1 & 1 & 1 & 1 \\
\hline Ansias 'náuseas' [nausea] (Arch.) & 1 & 1 & 0 & 1 & 0 & 1 & 1 & 1 & 1 \\
\hline Entodavía 'todavía' [still] & 1 & 0 & 0 & 1 & 1 & 1 & 1 & 1 & 1 \\
\hline Mercar 'comprar' [to buy] (Arch.) & 1 & 0 & 0 & 1 & 1 & 1 & 1 & 1 & 1 \\
\hline Urnia 'hucha' [piggybank] (Arch.) & 1 & 1 & 1 & 1 & 0 & 1 & 0 & 1 & 1 \\
\hline
\end{tabular}

\section{TABLE 5}

Proximity matrix (Jaccard index) ( $1=$ Andalusia; $2=$ Aragon and the Eastern coast; $3=$ Murcia; $4=$ Castile; $5=$ Northern penin sula; 6 = Western peninsula; 7 = Caribbean; 8 = Mesoamerica; 9 = South America)

\begin{tabular}{|l|l|l|l|l|l|l|l|l|l|}
\hline & Andalusia & $\begin{array}{l}\text { Aragon } \\
\text { and the } \\
\text { Eastern } \\
\text { coast }\end{array}$ & Murcia & Castile & $\begin{array}{l}\text { Northern } \\
\text { peninsula }\end{array}$ & $\begin{array}{l}\text { Western } \\
\text { peninsula }\end{array}$ & C & M & S \\
\hline 1 & 1 & 0.226 & 0.217 & 0.084 & 0.101 & 0.355 & 0.397 & 0.332 & 0.558 \\
\hline 2 & 0.226 & 1 & 0.782 & 0.157 & 0.094 & 0.216 & 0.116 & 0.081 & 0.101 \\
\hline 3 & 0.217 & 0.782 & 1 & 0.154 & 0.083 & 0.220 & 0.104 & 0.072 & 0.094 \\
\hline
\end{tabular}




\begin{tabular}{|l|r|r|r|r|r|r|r|r|r|}
\hline 4 & 0.084 & 0.157 & 0.154 & 1 & 0.116 & 0.146 & 0.058 & 0.063 & 0.061 \\
\hline 5 & 0.101 & 0.094 & 0.083 & 0.116 & 1 & 0.150 & 0.067 & 0.055 & 0.071 \\
\hline 6 & 0.355 & 0.216 & 0.220 & 0.146 & 0.150 & 1 & 0.150 & 0.120 & 0.168 \\
\hline 7 & 0.397 & 0.116 & 0.104 & 0.058 & 0.067 & 0.150 & 1 & 0.516 & 0.444 \\
\hline 8 & 0.332 & 0.081 & 0.072 & 0.063 & 0.055 & 0.120 & 0.516 & 1 & 0.454 \\
\hline 9 & 0.558 & 0.101 & 0.094 & 0.061 & 0.071 & 0.168 & 0.444 & 0.454 & 1 \\
\hline
\end{tabular}

The largest similarities occur in the American repertoires and between these repertoires and the Canary lexicon that concurs with AndaIusia. The least spread words are those shared between the Canary Islands, Andalusia, Castile, and the Northern peninsula. These last two regions never reach a 0.2 similarity index. Based on this proximity matrix, a tree diagram is obtained, in which it is possible to assess the classes into which the different regions analysed are grouped (Figure 1).
The data obtained by the ascending hierarchical classification establishes the following connections or networks, presented from the greatest to least number of concurrences:

1) Canary Islands, Andalusia and the American regions: 9, 7, and 8 (in order of concurrence, from greatest to least). The high number of concurrences with the South American region is surprising. The concomitants indicated by Corrales Zumbado \& Corbella Díaz

\section{FIGURE 1}

Tree diagram obtained from the similarity matrix ( $1=$ Canary Islands-Andalusia; $2=$ Aragon and the eastern coast; $3=$ Murcia; 4 = Castile; 5 = Northern peninsula; 6 = Western peninsula; 7 = Caribbean; 8 = Mesoamerica; 9 = South America)

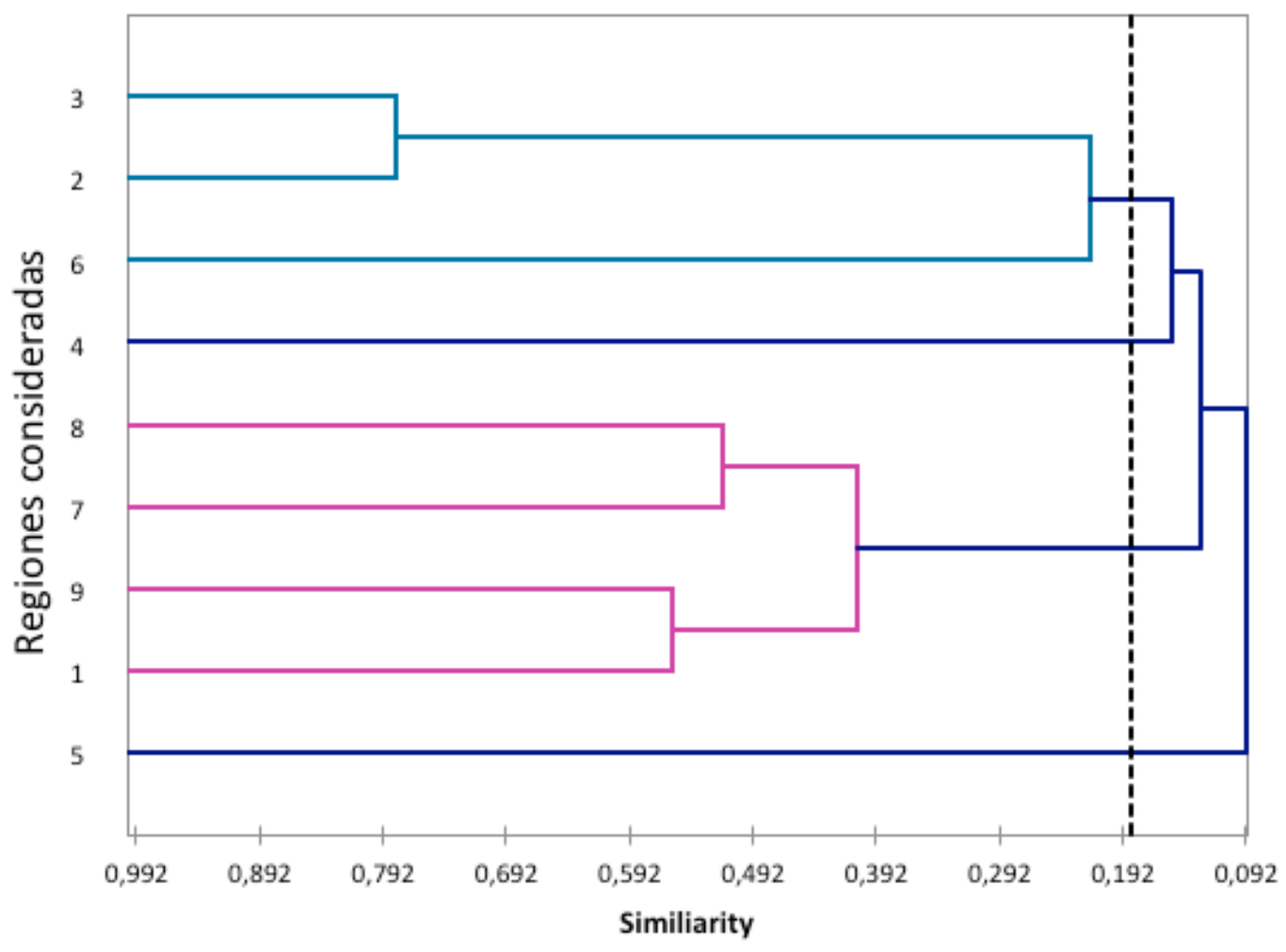


(2012) and Medina López (2013) are strengthened by quantitative data for the entire Canary lexicon, and this study confirms the Canary-Andalusian differential lexicon.

2) Canary Islands, Andalusia, and the eastern and Western peninsular regions: 2, 3, and 6. This vocabulary integrates Western and Eastern lexicons. In this group, the largest diffusers were Extremadura and Murcia. The group of terms that relate the Canary Islands, Andalusia, and the peripheral Spanish peninsular zones is smaller. These zones include Aragon (noted by Llorente Maldonado, 1985 and 2000, in the case of Andalusian), the Eastern coast, Murcia (indicated by Corbella Díaz, 1996), and the Western peninsula (Medina López, 2010; Cáceres Lorenzo, 2015). This group of concurrent words exhibits the oldest relationship, which was possibly established prior to the European colonisation of the Canaries, when the peninsular territory there was a common vocabulary for various languages. A specific vocabulary existed in recently conquered territories in which Western words - similar to GalicianPortuguese - and Eastern words - related to the languages of the kingdom of Aragon (e.g., clime, golismear, nano, fechar, tericia)shared a common communicative space (Frago Gracia, 1990 and 1994).

3) Canary Islands, Andalusia, and the regions of Castile and the Northern peninsula: 4 and 5 . This is a minority network, barely reaching fifty words, which would be expected when analysing a southern dialectal variety.

These results confirm that the lexical concurrences between the Canary Islands and Andalusia are more related to American than peninsular lexical repertoires. Equally interesting is a second observation regarding the presence of a second group of regions in the same class: Murcia, Aragon, the eastern coast, and the Western peninsula. These regions are geographic opposites but share much vocabulary with Andalusia and the Canaries. Information obtained from the regional dictionaries regarding the Canary-Andalusian lexicon's concurrence with Castile and the Northern peninsula demonstrates that these zones constitute distinct classes.

\section{Conclusions}

The empirical establishment of the connections between interregional lexicons in Atlantic Spanish means accepting the level of concurrence between pre-Hispanic dialectal variations. In this list of regional lexicon, there are many words that are slang with their corresponding phonic-graphic variation, eg 'desagerar exagera" [exaggerate]; 'chimenea' chimney [fireplace] or 'desinquieto inquieto' [restless]. This result is a consequence of the criteria of regional corpora that consider that any change in the signifier should appear. In the future, we believe it is possible to set up regional corpora in which these words will not appear. At the same time, the eight regions with which we compare the regional vocabulary can be changed in other researches that use other corpora or apply other criteria for gathering information.

In our results we may say that in the peninsular region, the level of concurrence should first be understood from north to south because the common Canary-Andalusian vocabulary has less in common with Northern Spanish. Furthermore, coexistence and proximity between border provinces condition the use of a common vocabulary in the peninsular territory. The data indicate that the possible linguistic levelling does not weaken the lexical richness of Atlantic Spanish. Rather, the idea is reinforced that the pre-Hispanic vocabulary formed an interconnected dialectal mosaic

American Spanish includes a significant representation of peninsular dialectal lexicon, which suggests the unique personality of the Atlantic vocabulary. The peninsular dialectal particularity (e.g., Andalusian, Aragonese, Leonese) of Atlantic Spanish becomes the general lexicon. 
Concurrence among distinct regional varieties is a result of the peninsular territory's linguistic contact.

The Canary-Andalusian synchronic dialectal lexicon confirms that the levelling process of Atlantic Spanish does not create a new, extremely different modality with enough sufficiently unique traits to constitute a language or a new dialect. What has been produced is a substitution mechanism of extensive lexical borrowing. This tendency has played a prominent role in the linguistic conformation of Atlantic Spanish. These data can be further complemented with other research that furthers more about the investigation of the lexicon of Western Andalusia, because the Andalusian is not a homogeneous linguistic variety.

\section{Bibliography}

Alba, Orlando, 1995: El español dominicano dentro del contexto Americano, Santo Domingo: Soto Castillo.

Alvar, Manuel, 1964: "Estructura del léxico andaluz", Boletín de Filología de la Universidad de Chile 16, 5-12.

Alvar, Manuel, 1990: "El camino de las Indias. Significación de las Islas Canarias" in Manuel Alvar (ed.): Norma lingüística sevillana y español de América, Madrid: Ediciones Cultura Hispánica, 63-84.

Alvar, Manuel, 1996: "Canario" in Manual de Dialectología Hispánica: el español de España, Barcelona: Ariel, 126-145.

Alvar Ezquerra, Manuel, 2000: Tesoro léxico de las hablas andaluzas, Madrid: Arco/Libro.

Ariza Viguera, Manuel, 1995: "Leonesismos y occidentalismos en las lenguas y dialectos de España”, Philologia hispalensis 10, 77-88.

Asociación de Academias de la Lengua Española, 2010: Diccionario de americanismos, Madrid: Santillana.
Bravo Garcia, Eva \& Ma. Teresa Caceres Lorenzo, 2011: La incorporación del indigenismo léxico en los contextos comunicativos canario y americano (1492-1550), Frankfurt: Peter Lang, Fondo Hispánico de Lingüística y Filología.

Buesa Oliver, Tomás, 1990: "Problemas para la identificación del andalucismo léxico en el español de América" in Bibiano Torres Ramirez (ed.): Actas de las VII Jornadas de Andalucía y América, Sevilla: Junta de Andalucía, t. II, 270-282.

Cáceres Lorenzo, Ma. Teresa, 2012: "Pugna entre lenguas romances e indigenismo en el español atlántico (1496-1600)", Bulletin of Hispanic Studies 89, 795-811.

Caceres Lorenzo, Ma. Teresa, 2015: "Portuguesismos y occidentalismos léxicos en las hablas canarias. Aportaciones desde el léxico dialectal sincrónico" in Serafina García García (coord.): Homenaje a José Antonio Martínez, Oviedo: Servicio de Publicaciones Universidad de Oviedo, t. I, 181-196.

Catalán, Diego, 1958: "Génesis del español atlántico. Ondas varias a través del océano", Revista de Historia Canaria 24, 233-242.

Claes, Jeroen, 2011: “¿Constituyen las Antillas y el Caribe continental una sola zona dialectal? Datos de la variable expresión del sujeto pronominal en San Juan de Puerto Rico y Barranquilla, Colombia”, Spanish in Context 8, 191-212.

Corbella Díaz, Dolores, 1996: "Fuentes del vocabulario canario: los préstamos léxicos" in Dolores CoRbella Díaz \& Javier Medina López (coord.), El español de Canarias hoy: análisis y perspectivas, Madrid/ Frankfurt: Iberoamericana/Vervuert, 105-142.

Corbella Diaz, Dolores \& Javier Medina López, 1996: "Lusismos en los diccionarios académicos: el caso de los dialectalismos canarios de origen portugués" in Juan M. Carrasco González y Antonio Viudas Camarasa (eds.): Actas del Congreso Internacional Luso-Español de Lengua y Cultura en la Frontera, Extremadura: Servicio de Publicaciones, 492-507. 
CoRominas, Joan, 1944: "Indianorrománica”, Revista de Filología Hispánica VI, 139-175.

Corrales Zumbado, Cristóbal, 1996: "Lexicografía canaria” in Dolores Corbella Díaz \& Javier Medina LóPEZ (coord.): El español de Canarias hoy: análisis y perspectivas, Madrid/Frankfurt: Iberoamericana/Vervuert, 143-178

Corrales Zumbado, Cristóbal \& Dolores Corbella Diaz, 2009: Diccionario ejemplificado de canarismos, La Laguna (Tenerife): Instituto de Estudios Canarios.

Corrales Zumbado, Cristóbal \& Dolores Corbella Diaz, 2012: "Historia y documentación del canarismo léxico", Cuadernos del Instituto de Historia de la Lengua 7, 143-180.

Corrales Zumbado, Cristóbal \& Dolores Corbella Díaz, 2013: "La impronta canaria en América: precisiones lexicográficas", Anuario de Estudios Atlánti$\cos 59,639-685$.

Corrales Zumbado, Cristóbal, Dolores Corbella Diaz, \& María Ángeles Álvarez Martínez, 1996: Diccionario Diferencial del Español de Canarias, Madrid: Arco Libros.

Elizaincin, Adolfo, 2007: "Ocho precisiones sobre el contacto lingüístico”, Lingüística 19, 117-132.

Figueroa Arencibia, Vicente Jesús, 2009: "Los contactos lingüísticos y el español no estándar de Santiago de Cuba”, Onomázein: Revista de lingüística, filología y traducción de la Pontificia Universidad Católica de Chile 20, 87-143.

Fontanella De Weinberg, María Beatriz, 1987: El español bonaerense. Cuatro siglos de evolución lingüística (1580-1980), Buenos Aires: Hachette.

Frago Gracia, Juan Antonio, 1990: "Nuevo planteamiento para la historia del occidentalismo léxico en el español de América" in Bibiano Torres Ramirez (ed.): Actas de las VII Jornadas de Andalucía y América, Sevilla: Junta de Andalucía, t. II, 151-167 Frago Gracia, Juan Antonio, 1994: El andaluz y el español de América: Historia de un parentesco lingüístico, Sevilla: Consejería de Cultura y Medio Ambiente, Junta de Andalucía.

Frago Gracia, Juan Antonio, 2000: "Fondo lingüístico canario y afinidades americanas (siglos XVIIXVIII)", Revista de Filología Española 80, 319-340.

García de Diego, Vicente, 1950: "El castellano como complejo dialectal y sus dialectos internos", Revista de Filología Española XXXIV, 107-124.

Granda, Germán de, 1994: Español de América, español de África y hablas criollas hispánicas: cambios, contactos y contextos, Madrid: Editorial Gredos.

Granda, Germán de, 2003: Estudios lingüísticos hispanoamericanos historia, sociedades y contactos, Frankfurt: Peter Lang.

Gries, Stefan, 2009: Statistics for Linguistics with $R$ : A Practical Introduction, Berlin: Mouton de Gruyter.

Hernandez Alonso, César, 2001: Diccionario del castellano tradicional, Valladolid: Editorial Ámbito.

IRIBARREN, José María \& Ricardo Ollaquindia, 1984: Vocabulario Navarro, Pamplona: Comunidad foral de Navarra, Departamento de Educación y Cultura, Institución príncipe de Viana.

Lebsanft, Franz, Wiltrud Minatsch \& Claudia PolzinHaumann, 2012: "Introducción" in Franz Lebsanft, Wiltrud Minatsch \& Claudia Polzin-Haumann: Variación diatópica, normas pluricéntricas y el ideal de una norma panhispánica, Madrid/Frankfurt: Iberoamericana/Vervuert, 7-18.

Le Men Loyer, Jeannick-Ivonne, 1998: Repertorio de léxico leonés, León: Universidad de León.

Llorente Maldonado, Antonio, 1985: "Coincidencias léxicas entre Andalucía y el Valle del Ebro", Archivo de Filología Aragonesa 36-37, 347-376.

Llorente Maldonado, Antonio, 2000: "Correspondencias entre el léxico salmantino y el léxico de Aragón, Navarra y Rioja", Archivo de Filología Aragonesa 56, 317-335. 
Lope Blanch, Juan Manuel, 1981: "Polimorfismo canario y polimorfismo mexicano" in Manuel Alvar LóPEz (coord.): I Simposio Internacional de Lengua Española, 275-288. Las Palmas de Gran Canaria: Cabildo Insular de Gran Canaria.

López Serena, Araceli. 2013. "La heterogeneidad interna del español meridional o atlántico: variación diasistemática vs. Pluricentrismo", Lexis 37, 95-161.

LüDTKE, Jens, 1998: "Plurilingüismo canario a raíz de la conquista" in Claudio García Turza, Fabio González Bachiller \& José Mangado Martínez (eds.): Actas del IV Congreso Internacional de Historia de la Lengua Española, Logroño: Universidad de La Rioja, 2, 513-522.

LÜDTKE, Jens, 2013: Los orígenes de la lengua española en América. Los primeros cambios en las Islas Canarias, las Antillas y Castilla del Oro, Madrid/Frankfurt: Iberoamericana/Vervuert.

Medina López, Javier, 2010: "José Pérez Vidal y América”, Boletín de Filología 45 (2), 287-315.

Medina López, Javier, 2013. "La formación lingüística de Canarias: sustratos, contactos e historia. Un balance de cinco siglos", Zeitschrift für Romanische Philologie 129 (2), 413-445.

Montero Curiel, Pilar, 1997: Vocabulario de Madroñera (Cáceres), Cáceres: Universidad de Extremadura, Servicio de Publicaciones UNEX.

Morgenthaler García, Laura, 2008: Identidad y pluricentrismo lingüístico: hablantes canarios frente a la estandarización, Madrid/Frankfurt: Iberoamericana/Vervuert.

Narbona Jiménez, Antonio, Rafael Cano Aguilar, Rafael \& Ramón Morillo-Velarde Pérez, 2011: El español hablado en Andalucía, Sevilla: Universidad de Sevilla.

Navarro Carrasco, Ana Isabel, 1988: Estructuras del léxico meridional según el ALEA, Málaga: Universidad de Málaga (UMA).
Neira Martínez, Jesús \& María del Rosario Piñeiro, 1989: Diccionario de los bables de Asturias, Oviedo: Principado de Asturias, Instituto de Estudios Asturianos.

Oesterreicher, Wulf, 2002: "El español, lengua pluricéntrica: perspectivas y límites de una autoafirmación lingüística nacional en Hispanoamérica. El caso mexicano", Lexis. Revista de Lingüística y Literatura 26, 275-304.

Pérez Vidal, José, 1991: Los portugueses en Canarias. Portuguesismos, Las Palmas de Gran Canaria: Cabildo Insular de Gran Canaria.

Rincón Alonso, M. Jesús, 1991: Vocabulario calagurritano, Calahorra: Diputación.

Rivarola, José Luis, 2007: "La formación de un objeto histórico: a propósito del español de América" in Daniel Jacob, Thomas Krefeld \& Wulf OesteRREICHER (eds.): Sprachgeschichte und Geschichte der Sprachwissenschaft, Tübingen: Gunter Narr, 169-178.

Rohlfs, Gerard, 1985: Diccionario dialectal del Pirineo aragonés, Zaragoza: Institución Fernando el Católico.

Saiz BarRIo, Miguel, 1991: Léxico cántabro, Santander: Tantín.

Salvador, Gregorio, 1967: "Elementos constitutivos: Iusismos" in en Manuel Alvar (dir.): Enciclopedia lingüística hispánica, Madrid: CSIC, t. II, 239261.

Salvador, Gregorio, 1987: "Discordancias dialectales en el español atlántico" in Estudios dialectológicos, Madrid: Paraninfo, 70-78

Sevilla Pérez, Alberto, 1990: Vocabulario murciano, Murcia: Editorial Sevilla.

Thompson, Sarah Grey \& Terrence Kaufman, 1988: Language contact, creolization, and genetic linguistics, Berkeley: University of California Press. 
UedA, Hiroto, 2013: "Una nota sobre el método de taxonomía cuantitativa de grandes datos. Coeficientes de asociación aplicados a las variantes del Diccionario de Americanismos", Dialectologia IV, 221-235. 